79 Kamat MA, Edgar L, Niblock P, McDowell C, Kelly CB. Association between antidepressant prescribing and suicide rates in oecd countries: an ecological study. Pharmacopsychiatry 2014; 47: 18-21.

80 Ludwig J, Marcotte DE, Norberg K. Anti-depressants and suicide. $J$ Health Econ 2009; 28: 659-76.

81 Ludwig J, Marcotte DE. Anti-depressants, suicide, and drug regulation. J Policy Anal Manage 2005; 24: 249-72.

82 Isometsa $\mathrm{E}$, Heikkinen $\mathrm{M}$, Henriksson $\mathrm{M}$, Aro $\mathrm{H}$, Lonnqvist J. Recent life events and completed suicide in bipolar affective disorder. A comparison with major depressive suicides. J Affect Disord 1995; 33: 99-106.

83 Oquendo MA, Dragatsi D, Harkavy-Friedman J, Dervic K, Currier D, Burke AK, et al. Protective factors against suicidal behavior in Latinos. J Nerv Ment Dis 2005; 193: 438-43.

84 Fountoulakis KN, Gonda X, Rihmer Z. Suicide prevention programs through community intervention. J Affect Disord 2011; 130: 10-6.

85 Rihmer Z, Gonda X, Fountoulakis KN. Suicide prevention programs through education in the frame of healthcare. Psychiatr Hung 2009; 24: 382-7.

86 Fountoulakis KN, Gonda X, Siamouli M, Rihmer Z. Psychotherapeutic intervention and suicide risk reduction in bipolar disorder: a review of the evidence. J Affect Disord 2009; 113: 21-9.

87 Gonda X, Fountoulakis KN, Kaprinis G, Rihmer Z. Prediction and prevention of suicide in patients with unipolar depression and anxiety. Ann Gen Psychiatry 2007; 6: 23 .

88 Stuckler D, Basu S, Suhrcke M, Coutts A, McKee M. The public health effect of economic crises and alternative policy responses in Europe: an empirical analysis. Lancet 2009; 374: 315-23.

89 Brenner M. Influence of the social environment on psychology: the historical perspective. In Stress and Mental Disorder (ed JE Barrett). Raven Press, 1979.

90 Jacob KS. The prevention of suicide in India and the developing world: the need for population-based strategies. Crisis 2008; 29: 102-6.

91 Tapia Granados JA. Increasing mortality during the expansions of the US economy, 1900-1996. Int J Epidemiol 2005; 34: 1194-202.

92 Stuckler D, Meissner C, Fishback P, Basu S, McKee M. Was the Great Depression a cause or correlate of significant mortality declines? An epidemiological response to Granados. J Epidemiol Community Health 2013; 67: 467.

93 Tapia Granados JA, Diez Roux AV. Life and death during the Great Depression. Proc Natl Acad Sci U S A 2009; 106: 17290-5.

94 Why are recessions good for your health? Natl Bur Econ Res Bull Aging Health 2012; 1: 1-2.
95 Ariizumi H, Schirle T. Are recessions really good for your health? Evidence from Canada. Soc Sci Med 2012; 74: 1224-31.

96 Ruhm CJ. Economic conditions and health behaviors: are recessions good for your health? N C Med J 2009; 70: 328-9.

97 Lee S, Guo WJ, Tsang A, Mak AD, Wu J, Ng KL, et al. Evidence for the 2008 economic crisis exacerbating depression in Hong Kong. J Affect Disord 2010; 126: 125-33.

98 Shi Z, Taylor AW, Goldney R, Winefield H, Gill TK, Tuckerman J, et al. The use of a surveillance system to measure changes in mental health in Australian adults during the global financial crisis. Int J Public Health 2011; 56: 367-72.

99 Economou M, Madianos M, Peppou LE, Patelakis A, Stefanis CN. Major depression in the era of economic crisis: a replication of a cross-sectional study across Greece. J Affect Disord 2013; 145: 308-14.

100 Portes A. Social capital: its origins and applications in modern sociology. Ann Rev Socio 1998; 24: 1-24.

101 Bourdieu P. The forms of capital. In Handbook of Theory and Research for the Sociology of Education (ed J Richardson): 241-58. Greenwood, 1986.

102 Ferragina E. Social Capital in Europe: A Comparative Regional Analysis. Edward Elgar Publishing, 2012.

103 Jain SH, Goyal R, Fox S, Shrank WH. Bowling alone, healing together: the role of social capital in delivery reform. Am J Manag Care 2012; 18 e209-11.

104 Evans $\mathrm{CH}$. Bowling alone: implications for academic medicine. Acad Med 1997; 72: $163-5$

105 Putnam R. Bowling alone: America's declining social capital. J Democracy 1995; 6: 65-78

106 Balint L, Dome P, Daroczi G, Gonda X, Rihmer Z. Investigation of the marked and long-standing spatial inhomogeneity of the Hungarian suicide rate: a spatial regression approach. J Affect Disord 2014; 155: 180-5.

107 Kapusta ND, Tran US, Rockett IR, De Leo D, Naylor CP, Niederkrotenthaler T, et al. Declining autopsy rates and suicide misclassification: a cross-national analysis of 35 countries. Arch Gen Psychiatry 2011; 68: 1050-7.

108 Moniruzzaman S, Andersson R. Relationship between economic development and suicide mortality: a global cross-sectional analysis in an epidemiological transition perspective. Public Health 2004; 118: 346-8.

109 Lucey S, Corcoran P, Keeley HS, Brophy J, Arensman E, Perry IJ. Socioeconomic change and suicide: a time-series study from the Republic of Ireland. Crisis 2005; 26: 90-4.

\title{
Addiction: biological aspects
}

\author{
David Nutt
}

Addiction, like cancer, is a strong word for a serious medical disorder. The experience of addiction is one of extreme drives that are resisted and recurrent episodes of despair as these drives overcome the best intentions of the patient. Stopping addictive behaviour leads to a period of withdrawal with at the least marked dysphoria and at the worst death. Almost everyone uses alcohol, tobacco or other drugs at some life stage, yet only a minority become addicted, proving specific individual vulnerabilities. These include significant genetic variables such as liver enzyme polymorphisms and brain processes such as dopamine and GABA dysfunction. 